\title{
Using Boron, Magnesium and some Amino Acids to Improve Yield and Fruit Quality of Roomy Red Grapevines
}

\author{
Mostafa A.A. Mohamed ${ }^{1}$; El-Sayed M. Qaoud ${ }^{* 2}$ \\ ${ }^{1}$ Hort. Dept. Fac. of Agric. Al- Azhar Univ. Assiut, Egypt. \\ ${ }^{2}$ Hort. Dept. Fac. of Agric. Suez Canal Univ. Ismailia, Egypt
}

Received: 10/12/2019

\begin{abstract}
This study was carried out during 2017 and 2018 seasons to study the effect of boric acid, Magnesium sulphate and some amino acids (Tryptophan, Methionine and Arginine) at $0.05 \%, 0.2 \%$ and $0.1 \%$ respectively, either alone or combination on solving clusters looseness, shot berries and coloration problems in Roomy Red grapevines grown under Minia region. Vegetative growth, vine nutritional status, berry setting \%, yield, cluster weight as well as physical and chemical characteristics of the berries were positively affected by using amino acids, magnesium sulphate and boric acid either as a single or in combinations when compared to the check treatment. Also, shot berries \% and total acidity reduced greatly with application of such treatments. Using boric acid, magnesium sulphate and amino acids influenced positively the studied characters in ascending order. Combined applications showed more effects rather than single ones in this respect. Three sprays of a mixture containing boric acid, Magnesium sulphate and some amino acids (Tryptophan, Methionine and Arginine) at $0.05 \%, 0.2 \%$ and $0.1 \%$, respectively, was responsible for obtaining higher yield, lower shot berries and clusters looseness as well as promoting berries quality of Roomy Red grapevines.
\end{abstract}

Keywords: boric acid, magnesium sulphate, amino acids, quality, yield, Roomy Red grapevines clusters looseness, shot berries

\section{INTRODUCTION}

Improving yield of Roomy Red grapevine quantitively and qualitatively as well as checking cluster looseness and shot berries are considered the most important tasks for pomologists in Egypt.

Therefore, the idea for using both boric acid, magnesium sulphate and some amino acids. Boron foliar spraying was found to be an effective method to increase boron level in reproductive and vegetative tissues rapidly. Applying boron must be done carefully because the available range between deficiency and toxicity is narrow (Peacock and Christensen, 2005). Reproductive tissues of grapevine are the most sensitive parts to boron deficiency which lead to reduce fruit set and causing negative effects on fruit quality and fruit yield. In addition, the over dose of boron can lead to plant phytotoxicity (Christensen and Smart, 2005). The different functions of boron for fruit trees are listed as follows (According to Adriano, 1985; Nijjar, 1985; Mengel et al., 2001).

1-Translocation and absorption of sugars, since sugars may be moved in the form of borate complexes.

2-Activating the formation of meristems.

3-Preventing the abortion of embryos.

4-Preventing the accumulation of polyphenolic compounds.

5-Incouraging root development.

6-Controlling the formation of starch and preventing the excessive concersion of sugars into starch.

7-Reducing, at the lower extent, the different disorders of the fruit crops.

Magnesium is essential for building chlorophylls, sugars, DNA, RNA, proteins, fats and amino acids. It is also responsible for enhancing uptake and sugars translocation (Nijjar, 1985).

Amino acids with their antioxidative properties play an important role in plant defense against oxidative stress induced by unfavorable conditions. Application of amino acids was accompanied with enhancing proteins biosynthesis as well as protecting plant cells from senescence and death, preventing the free radicals from oxidative of lipids the components of plasma membrane which is companied with the loss of permeability and controlling the incidence of disorders (Orth et al., 1993; Ahmed and Abd El-Hameed, 2003; Ahmed et al., 2007; Amin, 2007; Seleem-Basma and Abd El- Hameed, 2008; Sayed-Heba, 2010).

\section{MATERIALS AND METHODS}

This study was carried out during 2017 and 2018 seasons on forty-eight uniform in vigor 18-years-old head trained Roomy Red grapevines grown in a private vineyard located at Samalout district, Minia Governorate. The soil is silty clay; (Table 1), well drained with a water table not less than two meters deep. Dormant pruning in each season was done on the last week of Jan. The vines were trained as head pruning system by leaving 72 eyes ( 15 fruiting spurs $\mathrm{x}$ four eyes plus six replacement spurs $\mathrm{x}$ two eyes), planted at $2.0 \times 2.0$ meters apart under surface irrigation system. The vines received the usual horticultural practices that are already applied in the vineyard except those dealing with spraying any boric acid, magnesium sulphate and amino acids.

The present experiment involved eight treatments as follow:

1- Control

2- Boric acid at $0.05 \%(0.5 \mathrm{~g} / \mathrm{L})$

3- Magnesium sulphate at $0.2 \%(2 \mathrm{~g} / \mathrm{L})$

4- Amino acids at $0.1 \%(1 \mathrm{~g} / \mathrm{L})$

5- Boric acid + magnesium sulphate

6- Boric acid + amino acids

7- Magnesium sulphate + amino acids

8- Boric acid + magnesium sulphate + amino acids 
Table (1): Analysis of the tested soil

\begin{tabular}{lc}
\hline Constituents & Values \\
\hline Sand \% & 10.5 \\
Silt \% & 59.0 \\
Clay \% & 30.5 \\
Texture & Silty clay \\
pH (1: 2.5 extract) & 7.6 \\
E.C. (1: 2.5 extract, mmhos, 1 cm & 0.95 \\
25 C) & 2.02 \\
O.M. \% & 1.99 \\
CaCO3\% & 0.2 \\
Total N \% & 4.8 \\
Available P (Olsen method, ppm) & 522 \\
Available & (ammonium acetate, \\
ppm)
\end{tabular}

Each treatment was replicated three times with two vines per each. Boric acid (17\% B), magnesium sulphate $(9.6 \% \mathrm{Mg})$ and Amino acids (Tryptophan, Methionine and Arginine) were sprayed three times in each season at growth start (The $2^{\text {nd }}$ week of April). Just after berry setting (the first week of June) and one month later (the first week of July) and one month later. Triton was as a witting agent at $0.05 \%$ to all spraying solutions (2 liters/vine). The complete randomized block design was followed.

At the last week of July, during both seasons, growth characters namely main shoot length, number of leaves per shoot and leaf area $\left(\mathrm{cm}^{2}\right)$ (Ahmed and Morsy, 1999). Wood ripening coefficient was measured by dividing the length of brownish apart of the cane by the total length of cane just before pruning date (last week of Nov.) (Bourad, 1966) and after dormant pruning, weight of one-year-old wood (kg.) and cane thickness $(\mathrm{cm})$ were recorded, after completing of berry setting ( $2^{\text {nd }}$ week of June). Number of attached berries (number of attained berries) as well as number of dropped flowers and fruitlets were counted. Total number of flowers per cluster was estimated by summation of attached berries + dropped fruitlets + dropped flowers. Berry set was calculated by dividing number of attached berries per cluster by the total number of flowers per vine and multiplying the product by 100 .Plant pigments namely chlorophylls a, b (mg/100 g F.W.), total carotenoids (mg/100 g F.W.) in the leaves (Van-Wettstein, 1957) and percentages of $\mathrm{N}, \mathrm{p}, \mathrm{K}, \mathrm{Mg}, \mathrm{Zn}, \mathrm{Mn}$, and Fe (on dry weigh basis) were determined (Wild et al., 1985; Balo et al., 1988).

At harvesting date (last week of September during each season), yield expressed in weight $(\mathrm{kg})$ and number of clusters per vine were calculated. Five clusters per vine were picked for measuring quality parameters. Cluster weight (g) was also recorded. Number of shot berries were counted for each cluster and divided by total number of berries per cluster and the product is multiplied by 100 for calculating percentage of shot berries, total soluble solids, total sugars (Lane and Eynon, 1965) and total acidity (as tartaric acid/100 ml juice) according to (A.O.A.C., 2000) were determined in the juice.

All the obtained data were tabulated and statistically analyzed according to (Gomez and Gomez, 1984) and the averages were compared using new L.S.D. at $5 \%$ test.

\section{RESULTS AND DISCUSSION}

Effect of boric acid, magnesium sulphate and amino acids and there combinations on the vegetative growth

Data in Table (2) clearly showed that single and combined applications of boric acid, magnesium sulphate and amino acids at $0.05 \%, 0.2 \%$ and $0.1 \%$,respectively, significantly stimulated the min shoot length, number of leaves per shoot, leaf area, wood ripening coefficient pruning weight and cane thickness rather than unapplication. The stimulation on these growth characters was significantly depended on using boric acid, magnesium sulphate and amino acids in ascending order.

Application of amino acids occupied the first position in this respect while combined applications were significantly superior than using each material alone in stimulating the growth characteristics and wood ripening coefficient.

The maximum values of vegetative growth were recorded on the vines that received three sprays of mixture of boric acid, magnesium sulphate and amino acids at $0.05 \%, 0.2 \%$ and $0.1 \%$, respectively. Untreated vines recorded the lowest values. These results were similar in both seasons.

Effect of boric acid, magnesium sulphate and amino acids and there combinations on chlorophylls a, b and total carotenoids in the leaves

Varying boric acid, magnesium sulphate and amino acids had significant effect on the chlorophylls a, b and total carotenoids in the leaves (Table 3) foliar application of boric acid, magnesium sulphate and amino acids at $0.05 \%, 0.2 \%$ and $0.1 \%$, respectively, either applied alone or in various combinations significantly were accompanied with enhancing all pigments in the leaves rather than non- application. The promotion was significantly related to using boric acid, magnesium sulphate and amino acids in ascending order using the other two materials namely magnesium sulphate and boric acid. Double and triple applications were significantly favorable than using each alone in this respect. The maximum values of chlorophyll a $(3.92,3.96 \mathrm{mg} / 100 \mathrm{~g} \mathrm{FW})$, chlorophyll b $(1.93,1.95 \mathrm{mg} / 100 \mathrm{~g} \mathrm{FW})$ and total carotenoids (1.84, $1.87 \mathrm{mg} / 100 \mathrm{~g} \mathrm{FW}$ ) were observed on the vines that received all materials together. The minimum values of chlorophyll a $(3.50,3.46 \mathrm{mg} / 100 \mathrm{~g} \mathrm{FW})$, chlorophyll b (1.68, $1.67 \mathrm{mg} / 100 \mathrm{~g} \mathrm{FW})$ and total carotenoids (1.56, $1.56 \mathrm{mg} / 100 \mathrm{~g} \mathrm{FW}$ ) were presented on the vines that did not subject to any materials. Similar results were obtained during both seasons. 
Table (2): Effect of boron, magnesium and some amino acids on some vegetative growth of Roomy Red grapevines during 2017 and 2018 seasons

\begin{tabular}{|c|c|c|c|c|c|c|c|c|c|c|c|c|}
\hline \multirow[t]{2}{*}{ Treatments } & \multicolumn{2}{|c|}{$\begin{array}{l}\text { Main shoot } \\
\text { length (cm.) }\end{array}$} & \multicolumn{2}{|c|}{$\begin{array}{l}\text { No. leaf/ } \\
\text { shoot }\end{array}$} & \multicolumn{2}{|c|}{$\begin{array}{l}\text { Leaf area } \\
\quad(\mathrm{cm} .)\end{array}$} & \multicolumn{2}{|c|}{$\begin{array}{c}\text { Wood } \\
\text { ripening } \\
\text { coefficient }\end{array}$} & \multicolumn{2}{|c|}{$\begin{array}{c}\text { Cane } \\
\text { thickness } \\
(\mathrm{cm} .) \\
\end{array}$} & \multicolumn{2}{|c|}{$\begin{array}{c}\text { Pruning } \\
\text { weight/vine } \\
\text { (kg.) }\end{array}$} \\
\hline & 2017 & 2018 & 2017 & 2018 & 2017 & 2018 & 2017 & 2018 & 2017 & 2018 & 2017 & 2018 \\
\hline Control & 105.5 & 106.0 & 15.0 & 16.0 & 87.5 & 88.0 & 0.64 & 0.65 & 1.05 & 1.07 & 1.85 & 1.85 \\
\hline Boric acid at $0.05 \%$ & 107.0 & 107.3 & 16.0 & 17.0 & 89.0 & 89.9 & 0.66 & 0.67 & 1.09 & 1.10 & 1.87 & 1.89 \\
\hline $\begin{array}{l}\text { Magnesium sulphate } \\
\text { at } 0.2 \%\end{array}$ & 107.6 & 108.0 & 17.0 & 18.0 & 90.8 & 91.0 & 0.67 & 0.68 & 1.12 & 1.14 & 1.92 & 1.93 \\
\hline Amino acids at $0.1 \%$ & 109.0 & 109.5 & 18.0 & 19.0 & 92.0 & 93.0 & 0.70 & 0.71 & 1.14 & 1.15 & 1.95 & 1.96 \\
\hline $\begin{array}{l}\text { Boric acid }+ \\
\text { magnesium sulphate }\end{array}$ & 109.5 & 109.8 & 18.0 & 19.0 & 92.3 & 93.5 & 0.72 & 0.73 & 1.15 & 1.17 & 1.96 & 1.97 \\
\hline $\begin{array}{l}\text { Boric acid + amino } \\
\text { acids }\end{array}$ & 110.2 & 110.6 & 19.0 & 20.0 & 93.8 & 94.5 & 0.73 & 0.74 & 1.19 & 1.21 & 1.99 & 2.00 \\
\hline $\begin{array}{l}\text { Magnesium sulphate } \\
+ \text { amino acids }\end{array}$ & 112.0 & 112.5 & 20.0 & 21.0 & 94.5 & 95.6 & 0.74 & 0.75 & 1.23 & 1.23 & 2.05 & 2.10 \\
\hline $\begin{array}{l}\text { All together at same } \\
\text { conc. }\end{array}$ & 115.0 & 115.6 & 22.0 & 23.0 & 98.8 & 99.8 & 0.77 & 0.78 & 1.28 & 1.30 & 2.15 & 2.22 \\
\hline New L.S.D. at 5\% & 1.5 & 1.6 & 1.0 & 1.0 & 1.3 & 1.5 & 0.03 & 0.04 & 0.04 & 0.03 & 0.05 & 0.04 \\
\hline
\end{tabular}

Table (3): Effect of boron, magnesium and some amino acids on some leaf pigments and percentages of N, P and K in the leaves of Roomy Red grapevines during 2017 and 2018 seasons

\begin{tabular}{|c|c|c|c|c|c|c|c|c|c|c|c|c|}
\hline \multirow[t]{2}{*}{ Treatments } & \multicolumn{2}{|c|}{$\begin{array}{c}\text { Chlorophyll } \\
\text { a (mg/100 g } \\
\text { FW) }\end{array}$} & \multicolumn{2}{|c|}{$\begin{array}{c}\text { Chlorophyll } \\
\text { b (mg/100 g } \\
\text { FW) }\end{array}$} & \multicolumn{2}{|c|}{$\begin{array}{c}\text { Total } \\
\text { carotenoids } \\
(\mathbf{m g} / 100 \mathrm{~g} \\
\text { FW }) \\
\end{array}$} & \multicolumn{2}{|c|}{ Leaf N \% } & \multicolumn{2}{|c|}{ Leaf P \% } & \multicolumn{2}{|c|}{ Leaf K \% } \\
\hline & 2017 & 2018 & 2017 & 2018 & 2017 & 2018 & 2017 & 2018 & 2017 & 2018 & 2017 & 2018 \\
\hline Control & 3.50 & 3.46 & 1.68 & 1.67 & 1.56 & 1.56 & 1.66 & 1.65 & 0.15 & 0.14 & 1.10 & 1.10 \\
\hline Boric acid at $0.05 \%$ & 3.53 & 3.55 & 1.70 & 1.71 & 1.58 & 1.59 & 1.68 & 1.68 & 0.18 & 0.19 & 1.13 & 1.14 \\
\hline $\begin{array}{l}\text { Magnesium sulphate } \\
\text { at } 0.2 \%\end{array}$ & 3.60 & 3.63 & 1.75 & 1.77 & 1.62 & 1.64 & 1.71 & 1.72 & 0.19 & 0.21 & 1.15 & 1.16 \\
\hline Amino acids at $0.1 \%$ & 3.66 & 3.71 & 1.78 & 1.79 & 1.63 & 1.66 & 1.76 & 1.79 & 0.22 & 0.25 & 1.19 & 1.21 \\
\hline $\begin{array}{l}\text { Boric acid }+ \\
\text { magnesium sulphate }\end{array}$ & 3.72 & 3.77 & 1.82 & 1.85 & 1.68 & 1.71 & 1.78 & 1.80 & 0.24 & 0.26 & 1.21 & 1.23 \\
\hline $\begin{array}{l}\text { Boric acid + amino } \\
\text { acids }\end{array}$ & 3.74 & 3.80 & 1.84 & 1.86 & 1.70 & 1.73 & 1.83 & 1.85 & 0.28 & 0.30 & 1.28 & 1.28 \\
\hline $\begin{array}{l}\text { Magnesium sulphate } \\
+ \text { amino acids }\end{array}$ & 3.80 & 3.82 & 1.87 & 1.89 & 1.75 & 1.77 & 1.92 & 1.96 & 0.30 & 0.32 & 1.29 & 1.31 \\
\hline $\begin{array}{l}\text { All together at same } \\
\text { conc. }\end{array}$ & 3.92 & 3.96 & 1.93 & 1.95 & 1.84 & 1.87 & 2.00 & 2.08 & 0.35 & 0.38 & 1.33 & 1.35 \\
\hline New L.S.D. at 5\% & 0.03 & 0.04 & 0.2 & 0.3 & 0.3 & 0.3 & 0.04 & 0.06 & 0.03 & 0.03 & 0.03 & 0.03 \\
\hline
\end{tabular}

Effect of boric acid, magnesium sulphate and amino acids and there combinations on the leaf content of $N, P, N$ and $M g$ (as \%) and $\mathrm{Zn}, \mathrm{Fe}$ and Mn (as ppm) in the leaves

It is evident from the obtained data (Tables 3, 4) that single and combined application of boric acid, magnesium sulphate and amino acids at $0.05,0.2 \%$ and $0.1 \%$, respectively, was significantly $\mathrm{N}, \mathrm{P}, \mathrm{K}, \mathrm{Mg}, \mathrm{Zn}$, $\mathrm{Fe}$ and Mn comparing with the check treatment.

Spraying amino acids, magnesium sulphate and boric acid in descending order was significantly followed by enhancing these plant nutrients. Combined applications of these materials were significantly superior than using each material alone in enhancing these nutrients. The highest values of $\mathrm{N}(2.00,2.08 \%)$, $\mathrm{P}(0.35,0.38 \%), \mathrm{K}(1.33,1.35 \%) \mathrm{Mg}(0.88,0.93 \%)$, $\mathrm{Zn}(73.0,77.0 \mathrm{ppm}), \mathrm{Fe}(62.0,63.0 \mathrm{ppm}), \mathrm{Mn}(60.0$, $62.0 \mathrm{ppm})$ during both seasons, respectively were recorded on the vines that supplied with all material together at the second concentrations.

The untreated vines produced the minimum values of $\mathrm{N}(1.66,1.65 \%), \mathrm{P}(0.15,0.14 \%), \mathrm{K}(1.10$, $1.10 \%), \mathrm{mg}(0.55,0.56 \%), \mathrm{Zn}(50.0,51.0 \mathrm{ppm}), \mathrm{Fe}$ (50.2, $50.5 \mathrm{ppm}), \mathrm{Mn}$ (49.0, $49.2 \mathrm{ppm})$ during 2017 and 2018 seasons, respectively. These results were true during both seasons. 
Table (4): Effect of boron, magnesium and some amino acids on the leaf content of $\mathrm{Mg}$ (as \%) and $\mathrm{Zn}$, Fe and $\mathrm{Mn}$ (as ppm) in the leaves of Red Roomy grapevines during 2017 and 2018 seasons

\begin{tabular}{lccccccccc}
\hline \multirow{2}{*}{ Treatments } & \multicolumn{2}{c}{ Leaf Mg \% } & \multicolumn{2}{c}{ Leaf Zn ppm } & \multicolumn{2}{c}{ Leaf Fe ppm } & \multicolumn{2}{c}{ Leaf Mn ppm } \\
\cline { 2 - 9 } Control & $\mathbf{2 0 1 7}$ & $\mathbf{2 0 1 8}$ & $\mathbf{2 0 1 7}$ & $\mathbf{2 0 1 8}$ & $\mathbf{2 0 1 7}$ & $\mathbf{2 0 1 8}$ & $\mathbf{2 0 1 7}$ & $\mathbf{2 0 1 8}$ \\
\hline Boric acid at 0.05\% & 0.55 & 0.56 & 50.0 & 51.0 & 50.2 & 50.5 & 49.0 & 49.2 \\
Magnesium sulphate at 0.2\% & 0.56 & 0.57 & 54.0 & 56.0 & 51.5 & 52.0 & 49.9 & 50.0 \\
Amino acids at 0.1\% & 0.66 & 0.69 & 55.0 & 57.0 & 53.0 & 53.8 & 51.0 & 51.5 \\
Boric acid + magnesium sulphate & 0.68 & 0.71 & 61.0 & 64.0 & 55.2 & 56.0 & 53.0 & 54.2 \\
Boric acid + amino acids & 0.69 & 0.73 & 63.0 & 66.0 & 55.9 & 56.3 & 53.8 & 55.0 \\
Magnesium sulphate + amino acids & 0.71 & 0.74 & 71.0 & 75.0 & 57.0 & 58.0 & 55.2 & 57.1 \\
All together at same conc. & 0.79 & 0.81 & 72.0 & 76.0 & 59.2 & 59.9 & 56.1 & 58.0 \\
New L.S.D. at 5\% & 0.88 & 0.93 & 73.0 & 77.0 & 62.0 & 63.0 & 60.0 & 62.0 \\
\hline
\end{tabular}

Effect of boric acid, magnesium sulphate and amino acids and there combinations on the percentage of berry setting, yield as well as cluster weight and dimensions

Data concerning the effect of single and combined applications of boric acid, magnesium sulphate and amino acids, on the percentage of berry setting, yield as well as cluster weight and dimensions (length, shoulder) of Roomy Red grapevines during 2017 and 2018 seasons are shown in Table (5).

Percentage of berry setting, yield as well as cluster weight and dimensions were significantly improved due to using boric acid, magnesium sulphate and amino acids at $0.05 \%, 0.2 \%$ and $0.1 \%$, respectively, either singly or in all combinations rather than non application. Application of amino acids significantly surpassed the application of magnesium sulphate and boric acid in improving the five characters using magnesium sulphate occupied the second position. The last position was presented by using boric acid.

Combined applications were significantly and very favorable than using each material alone in enhancing the percentage of berry setting, yield as well as cluster weight and dimensions.

The best results were obtained on the vines that treated with the three materials together. Under such promised treatment. Berry setting (9.9, 10.3\%) yield/vine reached $(10.4,13.3 \mathrm{~kg})$ during both seasons respectively.

The untreated vines, percentage berry setting $(6.0,6.0 \%)$, yield were reached $(8.5,8.7 \mathrm{~kg})$ during both seasons, respectively. The percentage of increment on the yield due to application of the previous treatment over the check treatment reached 22.4 and $52.9 \%$ during both seasons respectively. These results were nearly the same during both seasons.

Table (5): Effect of boron, magnesium and some amino acids on the percentages of berry setting, yield as well as cluster number, weight and dimensions of Red Roomy grapevines during 2017 and 2018 seasons

\begin{tabular}{|c|c|c|c|c|c|c|c|c|c|c|c|c|}
\hline \multirow[t]{2}{*}{ Treatments } & \multicolumn{2}{|c|}{$\begin{array}{c}\text { Berry } \\
\text { setting \% }\end{array}$} & \multicolumn{2}{|c|}{$\begin{array}{l}\text { No. } \\
\text { clusters/vine }\end{array}$} & \multicolumn{2}{|c|}{$\begin{array}{l}\text { Yield/vine } \\
\text { (kg) }\end{array}$} & \multicolumn{2}{|c|}{$\begin{array}{c}\text { Cluster } \\
\text { weight (g) }\end{array}$} & \multicolumn{2}{|c|}{$\begin{array}{c}\text { Cluster } \\
\text { length }(\mathrm{cm})\end{array}$} & \multicolumn{2}{|c|}{$\begin{array}{c}\text { Cluster } \\
\text { shoulder } \\
(\mathrm{cm})\end{array}$} \\
\hline & 2017 & 2018 & 2017 & 2018 & 2017 & 2018 & 2017 & 2018 & 2017 & 2018 & 2017 & 2018 \\
\hline Control & 6.0 & 6.0 & 25.0 & 26.0 & 8.5 & 8.7 & 340.0 & 335.0 & 21.2 & 21.0 & 12.5 & 12.2 \\
\hline Boric acid at $0.05 \%$ & 7.2 & 7.4 & 26.0 & 27.0 & 9.1 & 9.5 & 350.0 & 359.0 & 22.0 & 22.0 & 12.8 & 12.8 \\
\hline $\begin{array}{l}\text { Magnesium sulphate } \\
\text { at } 0.2 \%\end{array}$ & 6.6 & 6.8 & 26.0 & 29.0 & 9.2 & 10.4 & 355.0 & 360.0 & 22.5 & 22.8 & 13.0 & 13.2 \\
\hline Amino acids at $0.1 \%$ & 7.3 & 7.5 & 26.0 & 31.0 & 9.6 & 11.6 & 370.0 & 375.0 & 23.0 & 23.2 & 13.3 & 13.5 \\
\hline $\begin{array}{l}\text { Boric acid + } \\
\text { magnesium sulphate }\end{array}$ & 7.7 & 7.9 & 27.0 & 31.0 & 10.2 & 11.9 & 380.0 & 385.0 & 23.5 & 23.7 & 13.6 & 13.8 \\
\hline $\begin{array}{l}\text { Boric acid }+ \text { amino } \\
\text { acids }\end{array}$ & 8.5 & 8.8 & 25.0 & 32.0 & 10.6 & 12.5 & 385.0 & 390.0 & 23.7 & 23.9 & 13.9 & 14.2 \\
\hline $\begin{array}{l}\text { Magnesium sulphate } \\
+ \text { amino acids }\end{array}$ & 8.2 & 8.5 & 26.0 & 33.0 & 10.1 & 13.0 & 390.0 & 395.0 & 23.9 & 24.2 & 14.3 & 14.5 \\
\hline $\begin{array}{l}\text { All together at same } \\
\text { conc. }\end{array}$ & 9.9 & 10.3 & 26.0 & 33.0 & 10.4 & 13.3 & 400.0 & 405.0 & 24.3 & 24.5 & 14.6 & 15.0 \\
\hline New L.S.D. at 5\% & 0.6 & 0.5 & NS & 2.0 & 0.6 & 0.8 & 11.0 & 9.5 & 0.5 & 0.4 & 0.3 & 0.2 \\
\hline
\end{tabular}


Effect of boric acid, magnesium sulphate and amino acids and there combinations on both physical and chemical characteristics of the berries

Data in Tables $(6,7)$ show the effect of single and combined applications of boric acid, magnesium sulphate and amino acids on berries coloration \%, shot berries $\%$, berry weight and dimensions (Longitudinal and equatorial) TSS $\%$, total sugars $\%$, total acidity $\%$ and TSS/acid in the berries of Roomy Red grapevines during 2017 and 2018 seasons.

A significantly promotion on fruit quality was observed owing to using boric acid, magnesium sulphate and amino acids at $0.05,0.2 \%$ and $0.1 \%$, respectively, either applied alone or when used in combinations comparing with the check treatment.

A significantly promotion on quality of the berries was observed due top using boric acid, magnesium sulphate and amino acids in descending order.

The promotion on quality of the berries was appeared in terms of increasing berries coloration \%, weight longitudinal and equatorial of berry, TSS \%, total sugars $\%$ and TSS/acid and decreasing shot berries $\%$ and total acidity $\%$ relative to check treatment. The best results were obtained due to using all materials together.

Table (6): Effect of boron, magnesium and some amino acids on the percentages of berries coloration and shot berries and some physical characteristics of Roomy Red grapevines during 2017 and 2018 seasons

\begin{tabular}{lcccccccccc}
\hline & \multicolumn{2}{c}{$\begin{array}{c}\text { Berries } \\
\text { coloration \% }\end{array}$} & $\begin{array}{c}\text { Shot } \\
\text { berries } \%\end{array}$ & $\begin{array}{c}\text { Av. Berry } \\
\text { weight (g.) }\end{array}$ & $\begin{array}{c}\text { Av. Berry } \\
\text { longitudinal } \\
\text { (cm) }\end{array}$ & $\begin{array}{c}\text { Av. Berry } \\
\text { equatorial } \\
\text { (cm) }\end{array}$ \\
\cline { 2 - 9 } & $\mathbf{2 0 1 7}$ & $\mathbf{2 0 1 8}$ & $\mathbf{2 0 1 7}$ & $\mathbf{2 0 1 8}$ & $\mathbf{2 0 1 7}$ & $\mathbf{2 0 1 8}$ & $\mathbf{2 0 1 7}$ & $\mathbf{2 0 1 8}$ & $\mathbf{2 0 1 7}$ & $\mathbf{2 0 1 8}$ \\
\hline Control & 60.0 & 60.0 & 5.0 & 5.2 & 4.80 & 5.00 & 2.00 & 2.00 & 1.70 & 1.74 \\
Boric acid at 0.05\% & 62.5 & 62.8 & 4.3 & 4.0 & 5.10 & 5.30 & 2.08 & 2.10 & 1.88 & 1.90 \\
Magnesium sulphate at 0.2\% & 63.2 & 63.7 & 4.0 & 3.8 & 5.40 & 5.50 & 2.11 & 2.13 & 1.95 & 1.99 \\
Amino acids at 0.1\% & 64.5 & 65.5 & 3.9 & 3.7 & 5.60 & 5.70 & 2.14 & 2.17 & 2.04 & 2.06 \\
Boric acid + magnesium sulphate & 64.8 & 65.9 & 3.6 & 3.4 & 5.70 & 5.80 & 2.20 & 2.25 & 2.08 & 2.10 \\
Boric acid + amino acids & 66.3 & 66.5 & 3.3 & 3.1 & 5.90 & 6.00 & 2.24 & 2.28 & 2.14 & 2.16 \\
$\begin{array}{l}\text { Magnesium sulphate + amino } \\
\text { acids }\end{array}$ & 66.5 & 68.0 & 2.9 & 2.7 & 5.99 & 6.06 & 2.31 & 2.35 & 2.15 & 2.22 \\
All together at same conc. & 70.0 & 72.0 & 2.6 & 2.5 & 6.08 & 6.10 & 2.38 & 2.40 & 2.18 & 2.20 \\
\hline New L.S.D. at 5\% & 0.3 & 0.6 & 0.5 & 0.4 & 0.10 & 0.11 & 0.05 & $0 . .05$ & 0.04 & 0.04 \\
\hline
\end{tabular}

Table (7): Effect of boron, magnesium and some amino acids on some chemical characteristics of the berries of Roomy Red grapevines during 2017 and 2018 seasons

\begin{tabular}{|c|c|c|c|c|c|c|c|c|}
\hline \multirow{2}{*}{ Treatments } & \multicolumn{2}{|c|}{ TSS \% } & \multicolumn{2}{|c|}{$\begin{array}{c}\text { Total sugars } \\
\% \\
\end{array}$} & \multicolumn{2}{|c|}{ Total acidity $\%$} & \multicolumn{2}{|c|}{ TSS/acid } \\
\hline & 2017 & 2018 & 2017 & 2018 & 2017 & 2018 & 2017 & 2018 \\
\hline Control & 17.8 & 17.5 & 16.2 & 16.0 & 0.690 & 0.695 & 25.80 & 25.18 \\
\hline Boric acid at $0.05 \%$ & 18.0 & 18.0 & 16.5 & 16.6 & 0.670 & 0.665 & 26.86 & 27.07 \\
\hline Magnesium sulphate at $0.2 \%$ & 18.2 & 18.5 & 16.7 & 16.9 & 0.659 & 0.649 & 27.61 & 28.51 \\
\hline Amino acids at $0.1 \%$ & 18.6 & 18.9 & 17.0 & 17.2 & 0.643 & 0.631 & 28.93 & 29.95 \\
\hline Boric acid + magnesium sulphate & 18.9 & 19.2 & 17.3 & 17.5 & 0.622 & 0.611 & 30.39 & 31.42 \\
\hline Boric acid + amino acids & 19.4 & 19.8 & 17.7 & 17.9 & 0.590 & 0.583 & 32.88 & 33.96 \\
\hline Magnesium sulphate + amino acids & 20.0 & 20.2 & 18.2 & 18.4 & 0.580 & 0.573 & 34.48 & 35.25 \\
\hline All together at same conc. & 20.4 & 20.8 & 18.5 & 18.9 & 0.566 & 0.560 & 36.04 & 37.14 \\
\hline New L.S.D. at 5\% & 0.5 & 0.4 & 0.3 & 0.2 & 0.017 & 0.015 & 0.93 & 0.98 \\
\hline
\end{tabular}




\section{DISCUSSION}

The beneficial effects of boron on stimulating vegetative growth characteristics, chlorophylls, nutrients, berry setting, yield and quality of the berries in grapevines cv Roomy Red might be attributed to its impact on according to Adriano (1985), Nijjar (1985), Fraguas and Silvo (1998).

These results are in agreement with those obtained by Ahmed and Abd El-Hameed (2003), Farahat (2008), Abd El-Gaber-Nermean (2009), Abd El-Wahab (2010), El- Kady-Hanaa (2011).

The beneficial effects of magnesium on yield and quality Red Roomy grapevines might be attributed to its essential roles on enhancing activity of different enzymes the biosynthesis and translocation of carbohydrates, fats, proteins and natural hormones, cell division, cell enlargement uptake of water and nutrients, building of chlorophylls and amino acids and seed formation (Nijjar, 1985; Mengel and Kirkby, 1987).

The results are in agreement with those obtained by Abd El-Gaber-Nermean (2009), Abd El-Wahab (2010), El-Kady-Hanaa (2011).

Amino acids with their antioxidative properties play an important role in plant defense against oxidative stress induced by unfavourable conditions. Application of amino acids was accompanied with enhancing proteins biosynthesis as well as protecting plant cells from senescence and death preventing the free radicals from oxidation of lipids the components of plasma membrane which the loss of permeability and controlling the incidence of disorders (Orth et al., 1993).

They are responsible for stimulating the bio synthesis of natural hormones like IAA, ethylene, cytokinins and $\mathrm{GA}_{3}$, cell division, organic foods, enzymes as well as DNA and RNA. These positive effects surely reflected on producing healthy trees.

These results are agreement with those obtained by Ahmed and Abd El- Hameed (2003), Amin (2007), Ahmed et al. (2011), Ibrahiem-Asmaa (2011), Madian and Refaai (2011), Mohamed (2014), Abada and Ahmed-Basma (2015).

\section{CONCLUSION}

Treating Roomy Red grapevines grown under Minia region conditions three times at growth start, just after berry setting and one month later with a mixtureofboric acid, magnesium sulphate and amino acids at $0.05 \%, 0.2 \%$ and $0.1 \%$, respectively, gave the best results with regard to yield and berry quality.

\section{REFERENCES}

Abada, M. A. M. and R. Ahmed-Basma (2015). The beneficial effects of using Royal Jelly, Arginine and tryptophane on fruiting of superior grapevines. Egypt. J. Hort., Vol. 42, No.1, pp. 345- 354.
Abd El- Gaber-Nermean, M. H. (2009). Response of Red Roomy grapevines to foliar application of boron, magnesium and zinc. M.Sc. Thesis, Fac. of Agric. Minia Univ., Egypt.

Abd El- Wahab, M. H. H. (2010). Relation of fruiting in superior grapevines with spraying sulphur magnesium, zinc and boron. M. Sc. Thesis, Fac. of Agric. Minia Univ., Egypt.

Adriano, D. C. (1985). Trace Elements in the terrestrial environment. Springer verlag, New York, pp. 20- 40.

Ahmed, A. H. and H. M. Abd El-Hameed (2003). Growth, uptake of some nutrients and productivity of Red Roomy vines as affected by spraying of some amino acids, magnesium and boron, Minia J. of Agric. Res. Develop., 23(4): 649-666.

Ahmed, F. F., A. Ibrahiem-Asmaa, A. E. M. Mansour, E. A. Shaaban and M. S. El-Shamaa (2011). Response of Thompson seedless grapevines to application of some amino acids enriched with nutrients as well as organic and biofertilization. Res. J. of Agric. and Biological Sci., 7(2): 2582-286.

Ahmed, F. F., M. A. Mohamed, A. M. K. Abd El- aal and M. M. Amin (2007). Response of red Roomy grapevines to application of amino acids and some micronutrients. $3^{\text {rd }}$ Conf. of Sustain Agric. and Develop., Fac. Agric., Fayoum Univ., Egypt, 12-14 Nov. pp. 150170 .

Ahmed, F. F. and M. H. Morsy (1999). A new method for measuring leaf area in different fruit species. Minia J. of Agric. Rec. \& Dev. 19: 97: 105.

Amin, M. M. A. (2007). Response of red Roomy grapevines to application of amino acids and some micronutrients M.Sc. Thesis, Fac. of Agric. Minia Univ. Egypt.

Association of Official Agricultural Chemists (A.O.A.C.) (2000). Official Methods of Analysis (A.O.A.C), $12^{\text {th }}$ Ed., Benjamin Franklin Station, Washington D.C., U.S.A. pp. $490-510$.

Balo, E., G. Prilessky, I. Happ, M. Kaholami and L. Vega (1988). Soil improvement and the use of leaf analysis for forecasting nutrient requirements of grapes. Potash Review (subject 9, 2nd suite, No. 61: 1-5).

Bouard, J. (1966). Recherche physiologique sur lavigbnw et en particullier pour laoutment des sarments. Tesis Sc. Nat Bordeaux (France) pp. 34.

Christensen, P. L. and D. R. Smart (2005). Foliar fertilization in vine mineral nutrient management programs. Proc. of the soil environment and vine mineral nutrition sym, san Diegu, California USA, 29-3 Junes pp, 10-20.

El- Kady-Hanaa, F. M. (2011). Productive performance of Thompson seedless grapevines in relation to application of some antioxidants, 
magnesium and boron. M.Sc. Thesis Fac. of Agric. Minia Univ. Egypt.

Farahat, I. A. M. (2008). Effect of some antioxidant and boron treatments on growth and fruiting of Red Globe grapevines. M.Sc. Thesis, Fac. of Agric., Minia Univ., Egypt.

Faguas, J. C. and U. J. Silvo (1998). Nutrition of grapevines in tropical regions. In tropical regions inform Agropccuiario, 19(194): 7075.

Gomez, K. A. and A. A. Gomez (1984). Statistical procedures for agricultural research Inter. Science Publication, John Wiley .pp. 20- 40.

Ibrahiem-Asmaa, A. H. (2011). Effect of some amino acids enriched with different nutrients on fruiting of red Roomy grapevines. Minia J. of Agric. Res. \& Develop. Vol. (31) L., No.1 pp. 49-59.

Lane, J. H. and L. Eynon (1965). Determination of reducing sugars by means of fehling's solution with methylene bleu as indicator AS.O.A.C. Washington D.C., USA pp. 490-510.

Madian, A. M. and M. M. Refaai (2011). The synergistic effects of using B vitamins with the two amino acids tryptophane and methionine in Thompson seedless grapevines Minia J. of Agric. Res. \& Develop Vol. (31): No. 3 pp. 445-454.

Mengel, K. E. and E. A. Kirkby (1987). Principles of plant nutrition. Worbaufen-Bern Switzerland, International Potash Institute, p. 10-20

Mengel, K. E., A. Kirkbt, H. Koesgarten and T. Appel (2001). Principles of plant nutrition 5th ElKluwer Academic publishers, Dordrecht, p. 1311.
Mohamed, W. B. F. (2014). Effect of some amino acids, nutrient and salicylic acid treatments on superior grapevines M.Sc. Thesis, Fac. Agric., Al Azhar Univ. Egypt.

Nijjar, G. S. (1985). Nutrition of fruit trees. Second edition Kalyani publishers, New Delhi India, pp. $179-272$.

Orth, A. B., A. Sfarra, R. J. Pell and M. Tien (1993). Assessing the involvement of free radicals in fungicide toxicity using $\mathrm{x}$ - tocopherol analos opesticide Biochemistry and Physiology, 47: 134-141.

Peackock, W. L. and L. P. Christensen (2005). Drop irrigation can effectively apply boron to san Joaquin Valley Vineyards. Calif. Agric., 59: 188-191.

Sayed-Heba, F. I. (2010). Effect of stimulant amino quelent - $\mathrm{Ca}$ and zinc on yield and berries quality of Thompson seedless grapevines. M.Sc. Thesis, Fac. of Agric., Minia Univ. Egypt.

Seleem, Basma, M. and H. M. Abd El-Hameed (2008). Effect of stimulant aminoquelent - ca on yield and berries quality of Thompson seedless grapevines. Minia J. Agric. Res. \& develop 28 (1), 13-21.

Van-Wettstein, D. V. (1957). Chlroophyll- Lethale under submikroshopische formilkechrel der plastiden celi, prp. Trop. Res. Amer. Soc. Hort. Sci. 20 pp. 427-433.

Wilde, S. A., R. B. Corey, J. C. Layer and G. K. Voigt (1985). Soils and Plant Analysis for Tree Culture. Oxford and IBH publishing Co., New Delhi. India, pp. 529-546. 


\title{
استخدام البورون والماغنسيوم وبعض الأحماض الأمينية لتحسين المحصول كما وجودة في كرمات

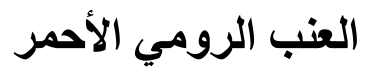

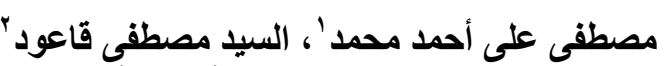

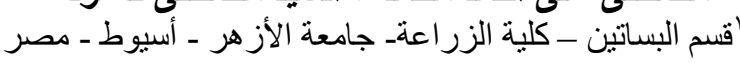

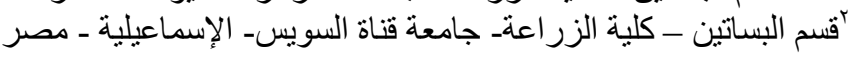

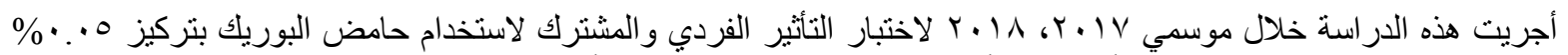

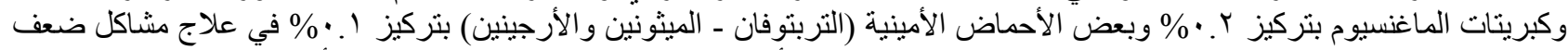

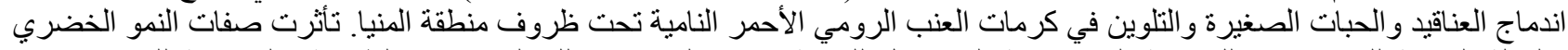

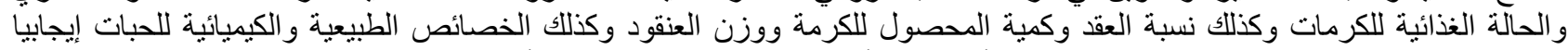

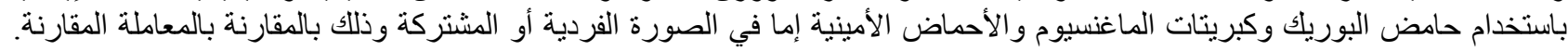

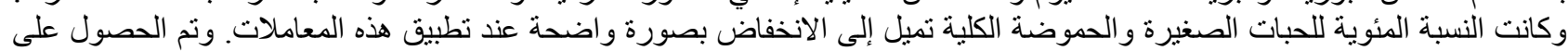

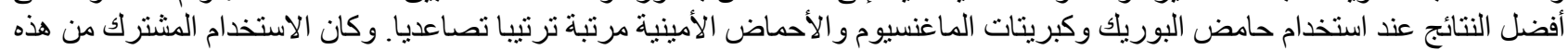

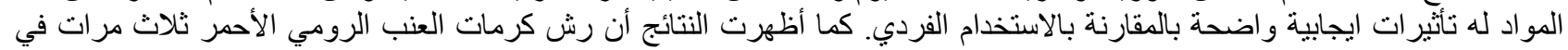

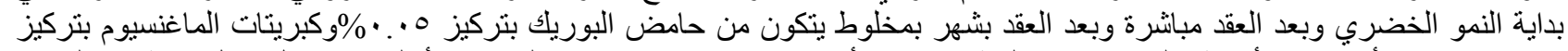

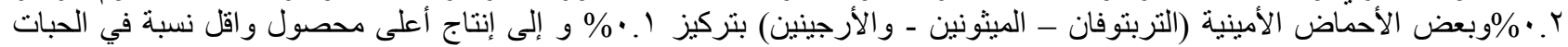

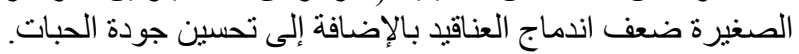

الكلمات الدالةه: الأحماض الأمينية ـ كبريتات الماغنسيوم- حامض البوريك ـ الجودة- المحصولـ العنب الرومي الأحمر- ضعف الندماج العناقيد- الحبات الصغيرة 